\title{
Sistem Pengawasan Dana Otonomi Khusus Aceh dan Dampaknya terhadap Pemberantasan Korupsi
}

\author{
Khairil Akbar, Zahlul Pasha Karim, Nyak Fadlullah, Muhammad Siddiq Armia \\ Universitas Syiah Kuala Banda Aceh \\ UIN Ar-Raniry Banda Aceh \\ khairilakbar@unsyiah.ac.id, zahlul.pasha@ar-raniry.ac.id, \\ nyak.fadlullah@ar-raniry.ac.id, msiddiq@ar-raniry.ac.id
}

\begin{abstract}
Aceh Special Autonomy Fund (DOKA) is the biggest corruption source that has driven distric heads to prison. This fact raises the question, how has DOKA monitoring system been carried out and what is the impact on corruption eradication? This study aims to examine those issues by using qualitative research with descriptive analysis techniques. The main findings indicate that DOKA is not seriously supervised. There is neither a special supervision system nor the specific institution to oversee the DOKA implementation. Thus, such a supervisory system needs serious improvement and comprehensive evaluation to maximize DOKA for manifesting the social welfare in Aceh.
\end{abstract}

Keywords: Supervision System, Aceh Special Autonomy Fund, Corruption, Aceh

\begin{abstract}
Abstrak
Dana Otonomi Khusus Aceh (DOKA) menjadi sumber korupsi terbesar yang mengantarkan para kepala daerah di Aceh ke dalam penjara. Fakta ini menimbulkan pertanyaan, bagaimana sistem pengawasan DOKA selama ini dilakukan dan apa dampaknya terhadap agenda pemberantasan korupsi? Penelitian ini bertujuan untuk menjelaskan sistem pengawasan DOKA dan dampaknya terhadap pemberantasan korupsi. Penelitian ini tergolong ke dalam jenis penelitian kualitatif dengan teknik analisis deskriptif. Temuan utama dalam penelitian menunjukkan bahwa DOKA tidak diawasi secara serius. Hal ini dapat dilihat dengan belum adanya sistem pengawasan khusus dan tidak digunakannya sistem pengawasan yang berlaku secara umum terhadap DOKA. Selain itu belum ada juga lembaga khusus yang memantau proses perencanaan sampai pada tahap pelaksanaan DOKA. Sistem pengawasan semacam itu tidak berdampak bagi pemberantasan korupsi. Perlu perbaikan serius dan evaluasi menyeluruh terhadap penggunaan dan penyaluran DOKA demi terwujudnya kesejahteraan sosial di Aceh.
\end{abstract}

Kata Kunci: Sistem Pengawasan, DOKA, Korupsi, Aceh 


\section{Pendahuluan}

Penelitian ini berusaha mengurai sistem pengawasan Dana Otonomi Khusus Aceh (DOKA) dan dampaknya terhadap pemberantasan korupsi di provinsi Aceh. Data yang dirilis KPK menyebutkan bahwa Aceh merupakan salah satu provinsi terkorup di Indonesia (Rahardjo, 2020). Penelitian KPK meletakkan keterlibatan kepala daerah yang tersangkut kasus korupsi menjadi salah satu indikatornya. Di samping Aceh, KPK juga menempatkan 5 (lima) provinsi lainnya sebagai provinsi terkorup di Indonesia. Kelima provinsi itu adalah Sumatera Utara, Riau, Banten, Papua dan Papua Barat. Parahnya, KPK memasukkan 3 (tiga) provinsi penerima Dana Otonomi Khusus sebagai daerah terkorup.

Bagi Aceh, Dana Otonomi Khusus pada prinsipnya merupakan bagian dari kebijakan desentralisasi asimetris yang baru dikenal pasca disahkannya UU 18 Tahun 2001 tentang Otonomi Khusus Bagi Daerah Istimewa Aceh sebagai Provinsi Nanggroe Aceh Darussalam. Setelah Aceh, di tahun yang sama Papua juga mendapat status Otonomi Khusus lewat UU 21 Tahun 2001 (Suharyo, 2018). Penting digarisbawahi bahwa Dana Otonomi Khusus hanya diberikan kepada beberapa provinsi yang didasarkan pada status kekhususan daerah tersebut. Aceh sendiri merupakan salah satu daerah dengan status istimewa dan khusus sekaligus yang mendapat Dana Otonomi Khusus di samping Papua dan Papua Barat yang hanya berstatus khusus. DOKA ini merupakan jalan tengah yang mulai diterima secara luas. Sebelumnya, konsep Dana Otonomi Khusus ini mendapat perlawanan dari kelompok Gerakan Aceh Merdeka (GAM) yang ingin memisahkan diri dari Negara Kesatuan Republik Indonsia (NKRI) (Suharyo, 2018).

Pasca tsunami Aceh tahun 2004, penambahan dan perbaikan terhadap keistimewaan dan kekhususan Aceh diwujudkan melalui pengesahan UU 11 Tahun 2006 tentang Pemerintahan Aceh dan upaya pengimplementasiannya. Hanya saja, butir-butir kesepakatan itu terkadang menjadi nihil pada praktiknya. Dana Otonomi Khusus yang ditujukan untuk mendorong laju perekonomian demi terwujudnya masyarakat Aceh yang sejahtera, justru dikorupsi oleh elit politik lokal. Salah satu cara melihat gagal atau berhasilnya realisasi Dana Otonomi Khusus yang dilekatkan kepada Aceh sejak tahun 2001 adalah dengan kacamata kesejahteraan. Kesejahteraan diletakkan sebagai tujuan akhir, sedangkan otonomi khusus merupakan cara atau upaya pencapaiannya. Namun faktanya, Dana Otonomi Khusus itu belum mampu menunjukkan peran signifikan dalam mengangkat kesejahteraan rakyat di Aceh. Kemiskinan masih menjadi permasalahan utama bagi Aceh (Heru Cahyono, 2012).

Elit politik lokal di Aceh kerap menjadikan kekhususan dan keistimewaan Aceh sebagai kambing hitam untuk meraih keuntungan sebesarbesarnya. Maka tidak heran jika sampai sekarang Aceh masih berada di bawah garis kemiskinan. Badan Pusat Statistik (BPS) Aceh bahkan menyatakan provinsi paling barat Indonesia ini masih menempati urutan tertinggi (peringkat pertama) daerah termiskin di Sumatra, dan berada di posisi ke 6 (enam) provinsi termiskin secara nasional (Nashih Nashrullah, 2020). Hal ini menimbulkan banyak pertanyaan dan membingungkan banyak pihak. Pasalnya, Pemerintah Indonesia telah menggelontorkan sejumlah uang berupa Dana Otonomi Khusus untuk mengatasi berbagai masalah di Aceh. Jika tetap miskin, lantas ke mana dana yang besar itu dipergunakan?

Pemanfaatan DOKA ditujukan untuk pembiayaan pembangunan dan pemeliharaan infrastruktur, disamping 
juga ditujukan untuk pemberdayaan ekonomi rakyat, pengentasan kemiskinan, serta pendanaan pendidikan, sosial, dan kesehatan (Kementerian Keuangan, n.d.). Dalam berbagai kesempatan, praktik korupsi terhadap DOKA ini berkisar pada pembiayaan pembangunan dan pemeliharaan infrastruktur, berhubung dua bagian pembiayaan ini memiliki nominal anggaran yang begitu besar. Selain itu, hampir bisa dipastikan semua proyek pembangunan di Aceh harus disisihkan untuk para mantan kombatan GAM sebagai bentuk kompensasi, atau lazim dikenal dengan istilah pajak nanggroe (illegal tax). 20 (dua puluh) bulan sebelum MoU Helsinki setidaknya telah terjadi 24 kali kutipan pajak nanggroe dan 20 (dua puluh) bulan setelah MoU Helsinki kutipan itu melonjak menjadi 29 kutipan (Siregar, 2012). Patrick Barron mengatakan:

"During the war, keuchiks were required to collect funds from the community and to give the money to GAM (pajak nanggroe) as well as to assist in the recruitment of both GAM and anti GAM militia. In the postconflict era, their salary and other benefits are considered inadequate" (Patrick, n.d.).

Selain itu, Aceh adalah wilayah bekas konflik yang sangat rentan dengan tindakan korupsi. Terdapat faktor keinginan untuk mengambil keuntungan oleh para pejabat publik yang berasal dari eks kombatan dengan anggapan bahwa mereka telah lama berjuang untuk mensejahterakan masyarakat Aceh. Sekarang adalah waktu untuk mengambil hak atas perjuangan yang telah dilakukan pada masa konflik. Korupsi DOKA sendiri telah terjadi berulang kali dan juga berpeluang untuk dikorupsi di kemudian hari. Sejauh ini, setidaknya, terdapat tiga kasus besar yang mengemuka terkait korupsi DOKA. Pertama, kasus Abdullah Puteh (KPK, 2017), kedua, kasus Irwandi Yusuf dan Ahmadi, dan yang ketiga, kasus Ruslan Abdul Gani. Artinya, korupsi DOKA bukan perkara baru.

Tiga kasus di atas berkaitan dengan DOKA, di mana dana ini merupakan penerimaan Pemerintah Aceh yang ditujukan untuk membiayai pembangunan (dan pemeliharaan) infrastruktur, pemberdayaan ekonomi rakyat, pengentasan kemiskinan, serta pendanaan pendidikan, sosial, dan kesehatan (Undang-Undang Nomor 11 Tahun 2006 Tentang Pemerintahan Aceh). Dana Otonomi Khusus yang sudah dan akan diterima Provinsi Aceh hingga tahun 2027 totalnya mencapai Rp.100.000.000.000.000,00, diambil dari 2\% Dana Alokasi Umum Nasional untuk 15 tahun pertama dan 1\% dari Dana Alokasi Umum Nasional pada 5 tahun berikutnya (Undang-Undang Nomor 11 Tahun 2006 Tentang Pemerintahan Aceh).

Tabel 1. Jumlah Anggaran DOKA dalam APBD Provinsi Aceh Tahun 2008/2015

\begin{tabular}{llc}
\hline Tahun & Besaran Dana & (\%) \\
\hline 2008 & Rp3.500.000.000.00 & - \\
\hline 2009 & Rp3.700.000.000.000 & 5.71 \\
\hline 2010 & Rp3.800.000.000.000 & 2.70 \\
\hline 2011 & Rp4.510.656.496.500 & 18.7 \\
\hline 2012 & Rp5.476.288.764.000 & 21.4 \\
\hline 2013 & Rp6.677.902.153.000 & 21.9 \\
\hline 2014 & Rp7.287.860.554.000 & 9.13 \\
\hline 2015 & Rp8.402.850.996.000 & 15.29 \\
\hline $\begin{array}{l}\text { Sumber: Kajian Pelaksanaan Dana Otonomi Khusus } \\
\text { Aceh, Pusat Pengembangan Keuangan Daerah } \\
\text { (PPKD), 2015 }\end{array}$ &
\end{tabular}

Sementara pada tahun 2016 hingga 2020 besaran DOKA 7,7 triliun, 8 triliun, 8 
triliun, 8,4 triliun, dan 8,4 triliun (Jayani, 2019). Besarnya dana tersebut kiranya menjadi faktor pendorong bagi koruptor untuk melirik yang kemudian mengambil tanpa hak Dana Otonomi Khusus yang semestinya ditujukan sebesar-besarnya untuk kepentingan rakyat Aceh. Hanya saja, korupsi terkadang bukan soal seberapa jumlah uang yang tersedia, melainkan juga persoalan sistem, pengawasan, kesempatan, dan banyak faktor lainnya. The Fraud Triangle Theory menjelaskan bahwa korupsi terjadi karena tiga hal: (1) pressure atau tekanan, (2) razionalitaion atau rasionalisasi/perhitungan dari pelaku (pressure dan razionalitation merupakan faktor internal), dan (3) opportunity atau kesempatan yang merupakan faktor eksternal (Cressey, 1953; Abdullahi dan Mansor, 2015).

Atas dasar itu, aspek pencegahan melalui mekanisme pengawasan yang telah berlaku selama ini kiranya menjadi faktor pendukung atas gagasan pemberantasan korupsi di Indonesia dan Aceh pada khususnya. Dapat dikatakan, jika aspek pengawasan Dana Otonomi Khusus ini lemah, maka akan semakin rentan Dana Otonomi Khusus itu dikorupsi. Sebaliknya, jika aspek pengawasan ini berjalan dengan baik dan terus dikembangkan, maka akan semakin kecil peluang seseorang untuk dapat melakukan aksinya.

Pengawasan merupakan fungsi yang tidak dapat dipisahkan dari pengelolaan anggaran yang modern, termasuk dalam pengelolaan DOKA. Fungsi pengawasan diperlukan untuk membantu manajemen bahkan setiap aktivitas penggunaan anggaran untuk mencapai tujuannya. Berbagai penelitian dalam pengawasan menunjukkan bahwa prinsipal (pemberi amanah) menghendaki adanya jasa pengawasan dalam rangka mengurangi permasalahan yang sering disebut sebagai konflik keagenan (Umar, 2012). Berkaitan pengawasan ini, Haryono Umar menyimpulkan bahwa adanya mekanisme manajemen yang didukung oleh pengendalian intern dan kepastian hukum akan menciptakan sistem yang mengurangi kesempatan seseorang untuk korupsi (Umar, 2012).

\section{Rumusan Masalah}

Berdasarkan penjelasan di atas, maka penelitian ini berupaya menjawab dua masalah penting, yakni: pertama, bagaimana sistem pengawasan Dana Otonomi Khusus Aceh (DOKA)? Kedua, bagaimana dampak pengawasan Dana Otonomi Khusus Aceh (DOKA) terhadap pencegahan dan penindakan korupsi di Aceh?

\section{Tujuan Penelitian}

Penelitian ini bertujuan untuk menjelaskan sistem pengawasan DOKA, dan juga menguraikan regulasi yang mengatur pengawasan DOKA, lembaga apa saja yang menjadi stakeholder dalam pengawasan DOKA, serta tata cara pengawasan itu dilakukan. Selain itu, penelitian ini juga ditujukan untuk melihat bagaimana dampak dari sistem pengawasan DOKA yang selama ini telah dilakukan.

\section{Lokasi Penelitian}

Penelitian ini mengambil tempat Provinsi Aceh secara keseluruhan, dengan teritorial penelitian berpusat di Kota Banda Aceh. Selain itu terdapat juga dua tempat lainnya, yakni Kabupaten Bener Meriah dan Kabupaten Aceh Tengah. Pemilihan Kota Banda Aceh sebagai teritorial utama mengingat semua pusat pemerintahan beserta stakeholders pada tingkat provinsi di Aceh berada dalam wilayah Kota Banda Aceh. Sementara pemilihan Kabupaten Bener Meriah dan Aceh Tengah sebagai wilayah penelitian 
pendukung yakni atas dasar penemuan dan terungkapnya kasus korupsi Dana Otonomi Khusus di Aceh yang melibatkan kepala daerah tingkat Kabupaten dan Provinsi.

\section{Tinjauan Pustaka}

Terdapat beberapa literatur yang bersinggungan dengan topik korupsi DOKA. Perihal Otonomi Khusus di Aceh dan aspek kesejahteraan masyarakat, sudah pernah ditulis oleh beberapa peneliti. Diantara beberapa peneliti tersebut, salah satunya adalah Suharyo yang menulis tentang "Otonomi Khusus di Papua dan Aceh sebagai Perwujudan Implementasi Peranan Hukum dalam Kesejahteraan Masyarakat" (Suharyo, 2016). Penelitian Suharyo menyimpulkan bahwa pembentukan daerah otonomi khusus adalah sebuah strategi politik yang akan berdampak positif terhadap kesejahteraan masyarakat dan juga dianggap responsif karena mampu menampung aspirasi masyarakat.

Selanjutnya Suharyo juga menulis tentang "Otonomi Khusus di Aceh dan Papua di Tengah Fenomena Korupsi (Suatu Strategi Penindakan Hukum)" (Suharyo, 2018). Hasil penelitiannya menyebutkan bahwa latar belakang maraknya praktek korupsi di Aceh adalah persoalan keamanan. Secara situasi politik, faktor transisi dari masa konflik dalam beberapa tahun terakhir menyebabkan daerah Aceh tidak mendapatkan perlakuan penegakan hukum secara serius dari Pemerintah Pusat. Pengaruh dari situasi politik inilah yang menyebabkan strategi penindakan tindak pidana korupsi di Aceh kurang represif.

Searah dengan penelitian tersebut, Heru Cahyono menulis tentang "Evaluasi Asas Pelaksanaan Otonomi Khusus Aceh: Gagal Menyejahterakan Rakyat dan Sarat Konflik Internal". Heru mengungkapkan bahwa pelaksanaan otonomi khusus di Aceh kurang berjalan sebagaimana mestinya, di bidang ekonomi misalnya, dana otonomi khusus tidak terkelola dengan baik sehingga membuat kesejahteraan masyarakat Aceh tidak mengalami perbaikan. Ironisnya, peningkatan kesejahteraan justru hanya dinikmati oleh sebagian orang yang dekat dengan kekuasaan, persoalan ini kemudian secara signifikan melahirkan fenomena orang-orang kaya baru di Aceh (Cahyono, 2012).

Beralih pada konteks pengawasan, penting melihat kajian Haryono Umar yang membahas tentang "Pengawasan untuk Pemberantasan Korupsi" (Umar, 2012). Haryono menjelaskan pengawasan melalui teknik audit memiliki kontribusi yang signifikan dalam strategi pemberantasan korupsi. Menurutnya kerugian negara dapat ditemukan dan ditekan dengan menerapkan audit yang efektif seperti audit forensik, audit investigatif, atau jenis audit lainnya.

Sejauh ini, beberapa penelitian yang telah diurut diatas meskipun memiliki keterkaitan secara umum, namun belum menyentuh persoalan yang ingin dikaji dalam peneltian ini. Oleh karena itu, penelitian ini penting dilakukan demi mengisi kekosongan terhadap kajian pengawasan DOKA. Dengan begitu, hasil penelitian ini akan berkontribusi terhadap keilmuan baru dari studi pemberantasan korupsi di Indonesia

\section{Metode Penelitian}

Penelitian ini menggunakan analisis kualitatif deskriptif. Sumber utama data terdiri dari data primer dan sekunder. Data primer diantaranya diperoleh dari wawancara dengan para pengambil kebijakan, perwakilan pemerintah daerah, akademisi, serta lembaga anti korupsi Gerak (Gerakan Anti Korupsi) Aceh sebagai masyarakat sipil anti korupsi. Data 
primer tersebut diperoleh melalui teknik wawancara secara tatap muka, wawancara virtual via aplikasi Zoom dan surat elektronik (e-mail). Sedangkan data sekunder berasal dari dokumen keuangan, dokumentasi pengawasan, serta studi literatur yang terkait dengan topik utama pembahasan penelitian ini. Seluruh data (baik primer maupun sekunder) yang sudah dikumpulkan dilakukan proses verifikasi untuk menghindari bias dan subjektifikasi terhadap kesimpulan penelitian. Proses verifikasi ini meminjam teknik Miles dan Huberman (Huberman, 1984).

\section{Pembahasan}

\section{A. DOKA sebagai Dana Kompensasi}

Konflik bersenjata yang terjadi selama tiga dekade menyebabkan Aceh tertinggal dari segala aspek. Selain itu, bencana gempa dan tsunami yang melanda sebagian wilayah Aceh (terutama Banda Aceh dan Meulaboh) memperparah kondisi tersebut. Konflik dan bencana menjadi salah satu pertimbangan utama terkait dengan pemberian Dana Otonomi Khusus kepada Provinsi Aceh. Dari persepktif kebijakan, DOKA tergolong kedalam kebijakan afirmatif (affirmative action) yang diambil untuk mendorong pertumbuhan ekonomi, pendidikan, pembangunan infrastruktur, dan beberapa aspek lainnya. Ini juga terlihat dari batasan pemberian dana otonomi khusus yang hanya berlaku selama 20 tahun. Batas waktu tersebut diperkirakan cukup untuk mengejar ketertinggalan dengan daerahdaerah lain yang ada di Indonesia.

Kebijakan afirmatif yang dimaksud jelas tertera pada Pasal 183 ayat (1) UUPA, yang menyatakan bahwa DOKA ini bertujuan untuk pembangunan dan pemeliharaan infrastruktur, pemberdayaan ekonomi rakyat, pengentasan kemiskinan, serta pendanaan pendidikan, sosial dan kesehatan.
Meskipun tujuan normatif sebagaimana diuraikan diatas dapat dibaca jelas, tidak dipungkiri bahwa apa yang sebenarnya dikehendaki pasca penandatanganan $\mathrm{MoU}$ Helsinki nyaris tidak terbahasakan di dalam UU a quo. Dana Otonomi Khusus dalam pemahaman yang lebih pragmatis merupakan dana kompensasi dari konflik.

"Saya pikir dana otonomi khusus itu kan konsekuensi dari perjanjian damai MoU Helsinki. Dan itu memang tertuang dalam poin-poin perjanjiannya bahwa ada 'kompensasi' terhadap korban konflik dan Aceh itu sendiri pasca damai". (Taufik A. Rahim, Dosen Ilmu Politik Universitas Muhammadiyah Aceh)

Meskipun disebut sebagai dana kompensasi, pengelolaan dana tersebut oleh banyak pihak dituntut agar dipertanggungjawabkan sesuai dengan sistem penganggaran yang ada (sesuai prosedur). Selain itu penggunaannya juga diharap tepat sasaran.

"Dana Otonomi Khusus Aceh itu semacam bantuan karena adanya kesenjangan di Aceh. Ia juga merupakan 'kompensasi' dari konflik Aceh. Oleh karena itu, pertanggungjawaban pengelolaan dana tersebut mesti diberlakukan layaknya anggaran-anggaran lainnya, bahkan harus lebih ketat. Sebab dana tersebut menyangkut masa depan pembangunan Aceh. Berhubung alokasi anggarannya besar, potensi penyelewengan juga pasti akan besar." (Askhalani, GERAK Aceh).

Hal ini dapat dilihat bagaimana fakta yang terjadi pada rentang waktu tahun 2008-2012, bahwa alokasi DOKA tidak terpantau dan terawasi. Dana Otonomi Khusus dibiarkan dikelola secara bebas yang hanya mengacu pada amanat perjanjian MoU Helsinki. Menurut Askhalani kondisi tersebut kemudian yang melatarbelakangi dibentuknya DES. Gunanya, sebagai pengontrol bagi DOKA 
dalam mengawasi mekanisme transfer, bahkan pada awal pembentukan pernah mengawasi dan mengaudit secara khusus DOKA. Terlepas dari itu semua, pemberian Dana Otonomi Khusus kepada Aceh tidak dapat dipisahkan dari landasan sosiohistori yang berkelit kelindan dengan konflik, aspek yang menyebabkan Aceh mengalami ketertinggalan secara pembangunan.

\section{B. Penggunaan dan Penyaluran Dana Otonomi Khusus Aceh}

Badan Pusat Statistik Aceh (BPS Aceh) pada awal Januari 2020 mengeluarkan laporan yang menunjukkan selama periode tahun 2016 sampai dengan 2019, jumlah dan persentase penduduk miskin di Aceh berfluktuasi (BPS Aceh, 2019). Data tersebut menunjukkan bahwa kemiskinan masih menjadi permasalahan utama bagi Aceh.

Menurut Heru Cahyono (2016), ada dua persoalan mendasar yang melatari kesalahan pengelolaan DOKA, yakni menyangkut dalam bidang ekonomi dan politik. Dalam bidang ekonomi, dana otonomi khusus tidak terkelola dengan baik sehingga membuat kesejahteraan masyarakat Aceh secara umum tidak mengalami perbaikan. Ironisnya, peningkatan kesejahteraan justru hanya dinikmati oleh segelintir orang yang dekat dengan kekuasaan sehingga menimbulkan fenomena orang-orang kaya baru di sana. Salah satu sebab di bidang ekonomi ini karena DOKA cenderung diarahkan untuk meningkatkan popularitas gubernur yang memang berniat maju kembali dalam pilkada Gubernur. Contoh yang paling mengemuka ialah mengenai proyek Jaminan Kesehatan Aceh (JKA), pembangunan dua jembatan fly over di Banda Aceh, dan renovasi Mesjid Raya Baiturrahman.

Sementara dalam bidang politik, dominasi mantan GAM di pemerintahan dan parlemen, baik di provinsi maupun tingkat kabupaten/kota sangat kuat terjadi. Namun, keberadaan mereka justru tidak diikuti dengan kapabilitas yang memadai sehingga kinerja parlemen maupun pemerintahan mengalami penurunan kualitas dan menjurus kolusi, sedangkan di sisi lain korupsi merajalela. Kondisi di atas nampaknya selaras dengan Laporan dari Kementerian Keuangan (Kemenkeu) tentang penggunaan DOKA (Kemenkeu, 2020). Dalam laporan tersebut dijelaskan beberapa hal, di antaranya: Pertama, Pemerintah Daerah kurang transparan. Kedua, ketergantungan yang masih tinggi terhadap DOKA. Ketiga, kinerja indikator kesejahteraan dan perekonomian daerah selama implementasi DOKA pada periode 2011-2017 telah menunjukkan perbaikan, namun signifikansi pengaruh DOKA terhadap membaiknya kinerja indikator tersebut belum dapat dijelaskan. Dan masih terdapat catatancatatan lainnya.

Adapun persoalan penyaluran dana otonomi khusus juga kerap menjadi sorotan, bahkan oleh Presiden Republik Indonesia. Jokowi menyebut bahwa dana yang dikucurkan ke Aceh dengan jumlah yang begitu besar mestinya dikelola dengan baik. Totalnya mencapai $17 \mathrm{~T}$, dengan pembagian Dana Otonomi Khusus Aceh sebanyak $8 \mathrm{~T}$, dan APBA sebanyak 9 T. Angka sebesar itu harus dipergunakan sebaik mungkin dan dikelola dengan benar (AJNN, 2020). Apa yang disampaikan Jokowi sebenarnya merupakan pertanyaan bahkan pernyataan bahwa DOKA belum tepat sasaran. Fakta bahwa Aceh berada sebagai Provinsi termiskin di Sumatera dan Indonesia adalah bukti betapa DOKA belum tepat sasaran.

Belakangan, dengan merebaknya wabah COVID-19 di Indonesia, semakin memperparah ketidaktepatan penggunaan dan penyaluran DOKA. 
Laporan dari Gerak Aceh, bahwa terdapat alokasi anggaran sebanyak 100 Juta untuk setiap sekolah di Aceh dengan tujuan pembelian/pembuatan tempat cuci tangan untuk kebutuhan standar protokol kesehatan bagi siswa. Menurut kajian Gerak, anggaran tersebut sangat tidak masuk akal, dan masuk dalam resiko besar untuk diselewengkan.

Selain itu, laporan dari Kejaksaan Tinggi Aceh juga menyebutkan bahwa DOKA yang disalurkan pada saat ini dalam bentuk hibah sedang ditangani dan masih dalam pengembangan kasus.

"Hal ini termasuk bentuk penyelewengan dan tentunya menjadi titik lemah dari penyaluran DOKA. Bisa jadi penyalurannya benar, namun tercium aroma yang tidak wajar dan sengaja dilakukan agar penyaluran itu justru masuk ke kantong-kantong orang yang tidak berhak menerimanya. Angka yang besar dalam setiap paket proyek sengaja dipecah-pecah untuk menghindari proses lelang. Padahal, dengan proses lelang saja belum terjamin proyek yang didapatkan oleh para kontraktor itu melalui prosedur yang bersih dan transparan, apalagi jika pelelangan tidak dilakukan." (Syahdansyah, Kejaksaan Tinggi Aceh).

Pada kasus yang lain, terdapat juga contoh betapa penyaluran DOKA selama ini tidak tepat sasaran:

"Pembangunan pasar sayur yang terletak di Gampong Cunda Meunasah Mesjid. Bangunan itu sudah dua kali direnovasi tapi tidak difungsikan oleh masyarakat," (Yulius Darma, UNIMAL, 2019).

Beberapa contoh penyelewengan diatas memiliki beberapa aktor utama, sebagaimana pola penyelewengan yang lazim terjadi di berbagai daerah.

"Apa yang terjadi selama ini adalah karena sejak dari perencanaan DOKA memang sudah berpotensi dikorupsi. Dulu melalui aspirasi, sekarang disebut pokir. Awalnya di sanalah proses lobi politik dilakukan. Jadi, jika dipetakan, penyaluran DOKA itu awalnya hanya terpusat pada tiga aktor utama: DPRA, TAPA (Tim Anggaran Pemerintah Aceh), dan Gubernur Aceh. Kalau ingin mendapat jatah, lobinya ke tiga aktor itu. Dan merekalah yang dapat mengotak-atik DOKA," (Askhalani, 2020).

Seiring dengan perubahan sistem (baca: Qanun), aktor-aktor yang memengaruhi penyaluran DOKA ini juga berubah. Meski dari sisi aktor awalnya korupsi memang dilakukan secara bersama-sama, namun setidaknya terdapat fungsi kontrol di sana, sekarang nyaris tidak ada sama sekali.

"Dulu meski Gubernur juga sangat berperan, tapi setidaknya dana ditransfer langsung ke daerah (Kabupaten/Kota). Sekarang, pembelanjaannya juga dilakukan oleh Provinsi. Mekanisme penyaluran DOKA itu hari ini ya bergantung pada SKPA, Pokja ULP, dan Gubernur. DPRA malah nyaris tidak terlibat kali ini," (Askhalani, 2020).

Perihal aktor berpengaruh dalam penyaluran DOKA, menurut Taufik A. Rahim pihak legislatif juga memberi intervensi perencanaan yang terkait dengan DOKA.

"Biasa ke dinas-dinas dan DPRA. Tekanan legislatiflebih kuat dibanding kepala dinas. Karena posisi legislatif sejajar dengan eksekutif. Terkadang terjadi pertengkaran di TAPA karena terjadi perubahan di TAPA akan tetapi tidak sesuai perencanaan Bappeda." Taufik A. Rahim.

Penyaluran DOKA ini dilakukan bertahap dengan ketentuan $60 \%$ untuk Kabupaten/Kota dan 40\%-nya untuk Provinsi. Awalnya dana tersebut langsung 
ditransfer. Sekarang Kabupaten/Kota hanya mengusulkan, sedangkan persetujuan dan pembelanjaannya dilakukan oleh Provinsi.

\section{Pengawasan Dana Otonomi Khusus Aceh}

\section{Sistem Pengawasan Dana Otonomi Khusus Aceh}

Peran pengawasan untuk meyakinkan bahwa semuanya akan berjalan sesuai dengan komitmen yang telah ditetapkan (regulasi). Selain itu, pengawasan juga memberi umpan balik apakah untuk perencanaan mendatang dapat dilakukan berdasarkan hasil-hasil pengawasan atas pelaksanaan kegiatan pada periode sebelumnya (Haryono Umar, 2012). Kaitannya dengan DOKA, pengawasan harusnya dilakukan guna mengukur kesesuaian komitmen tersebut dan pada gilirannya akan memberikan rekomendasi bagaimana DOKA itu semestinya diperlakukan pada periode atau tahun anggaran berikutnya. Di sini, kiranya bukan sekadar untuk menciptakan sistem yang mengeliminir "niat jahat", juga dalam tempo yang lebih panjang harusnya dapat mengurangi niat dan peluang perilaku korupsi. Untuk itu, paradoks-paradoks keberhasilan represif harus dibarengi efektifitas pengawasan preventif dan edukatif (Umar 2012).

Sayangnya, DOKA selalu mengabaikan aspek evaluasi dari berbagai stakeholder yang ada. Penyaluran DOKA sama sekali tidak berdasar pada kinerja periode sebelumnya, melainkan pada besaran yang telah ditetapkan oleh undang-undang. Hal ini cukup beralasan mengapa DOKA kerap dikorup; selain jumlahnya yang besar, DOKA juga cenderung stabil untuk periode 20 tahun mendatang. Tidak ada intervensi yang dapat mengurangi besaran anggaran ini karena undang-undang telah menetapkan batas minimalnya. Berbeda dengan sumber anggaran lainnya, serapan
DOKA tidak memengaruhi jumlah DOKA pada masa berikutnya. Lagi pula, DOKA ini kerap dipandang sebagai kompensasi bagi Aceh atau setidaknya bagi mereka yang sedang berkuasa di Aceh.

Hasil penelitian ini menemukan bahwa tidak ada sistem pengawasan khusus yang digunakan untuk mengawasi penyaluran Dana Otonomi Khusus Aceh (DOKA), selain itu tidak ada juga lembaga khusus yang memantau proses perencanaan sampai pada tahap pelaksanaan DOKA. Meskipun demikian, pembahasan dibawah ini akan mengurai bagaimana dan sejauh mana pengawasan terhadap DOKA dilakukan. Keterangan utama yang diambil terdiri dari berbagai hasil wawancara di beberapa institusi negara yang berhubungan dengan persoalan ini, beberapa institusi tersebut diantanya adalah; Inspektorat Provinsi dan Kabupaten, BPK, BPKP, Kejaksaan Negeri, serta Bappeda Provinsi Aceh.

\section{Regulasi Pengawasan Dana Otonomi Khusus Aceh}

Selain UU Nomor 11 Tahun 2006, Pemerintah Aceh juga memiliki Rencana Induk Pemanfaatan Dana Otonomi Khusus (RIPDOK) melalui Peraturan Gubernur Aceh Nomor 78 Tahun 2015 tentang Rencana Induk Pemanfaatan Dana Otonomi Khusus Aceh Tahun 2008-2027 (Berita Daerah Aceh Tahun 2015 Nomor 83) dan Pergub Aceh Nomor 114 Tahun 2018 Tentang Perubahan atas Peraturan Gubernur Nomor 78 Tahun 2015 tentang Rencana Induk Pemanfaatan Dana Otonomi Khusus Aceh Tahun 2008-2027. Sejak tahun 2008, telah terjadi perkembangan dan perubahan pola penggunaan dana otonomi khusus di Aceh, terkait hal itu sudah dilakukan 4 tahapan pembaruan atas Qanun yang mengatur mekanisme pengelolaan dana otonomi khusus Aceh. 
Diantara beberapa perubahan Qanun tersebut adalah; Qanun Nomor 2 Tahun 2008 (berlaku dari 2008 hingga 2013), Qanun Nomor 2 Tahun 2013 (berlaku dari tahun 2014 hingga tahun 2017), Qanun Nomor 10 Tahun 2016 (berlaku hanya satu tahun yakni pada 2018), Qanun Aceh Nomor 1 Tahun 2018 (berlaku dari tahun 2019 hingga sekarang). Hal-hal yang diatur dalam qanun tersebut diantaranya: pertama menyangkut alokasi dana untuk tingkat provinsi dan kabupaten/kota, kedua formula alokasi dana untuk kabupaten/kota, ketiga penetapan dan alokasi pengelolaannya bagaimana mekanismenya, keempat perencanaannya, dan yang kelima pelaksanaannya.

Pada umumnya informan menghubungkan regulasi yang mengatur pengawasan DOKA (Dana Otonomi Khusus Aceh) dengan Qanun Aceh No 2 Tahun 2008 tentang Tata Cara Pengalokasian Tambahan Dana Bagi Hasil Minyak dan Gas Bumi (disertai dengan perubahanperubahannya). Juga mayoritas informan menghubungkan regulasi tentang pengawasan DOKA ini dengan peraturanperaturan lain yang berkaitan dengan pengelolaan keuangan daerah secara umum. Qanun ini dan perubahanperubahannya bukan merupakan peraturan yang mengatur tentang pengawasan DOKA, seperti ditegaskan terutama oleh BPKP Aceh, Bappeda dan Inspektorat Bener Meriah.

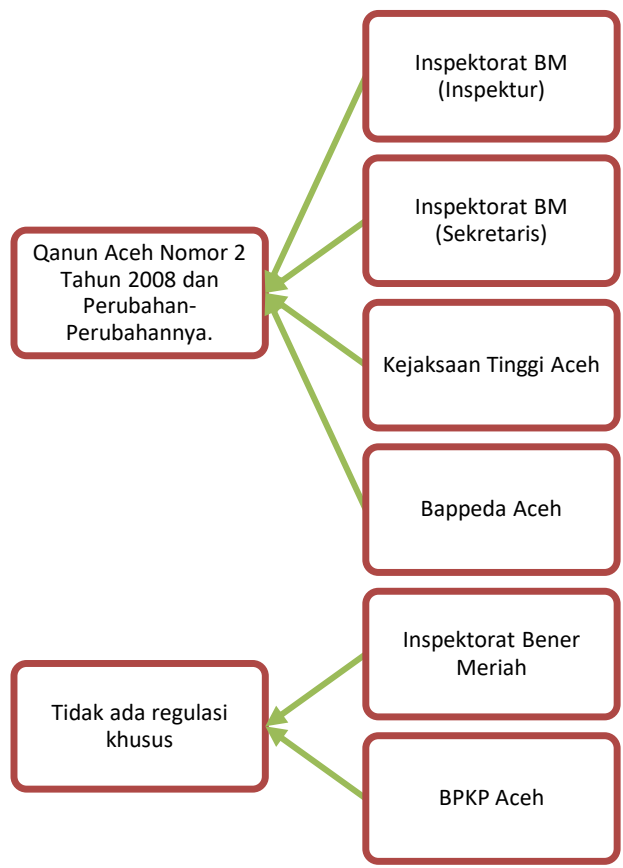

Gambar 2. Regulasi Pengawasan Dana Otonomi Khusus Aceh

\section{Lembaga Stakeholder dalam Pengawasan DOKA}

Pengawas utama yang paling berwenang dan bertanggungjawab atas dana otonomi khusus ini adalah Pemerintah Pusat. Selain memiliki tugas pembinaan, Pemerintah pusat juga memiliki tugas mengawasi aliran DOKA, yang mana aliran dana tersebut bagian dari terselenggaranya urusan pemerintah daerah. Hal ini sebagaimana bunyi Pasal 7 Undang-Undang Nomor 23 Tahun 2014 tentang Pemerintah Daerah, bahwa "Pemerintah Pusat melakukan pembinaan dan pengawasan terhadap penyelenggaraan urusan pemerintah daerah". Dengan begitu kementerian secara umum melaksanakan tugas pembinaan dan pengawasan dibantu oleh kementerian atau lembaga pemerintah non-kementerian terkait pelaksanaan pembinaan secara teknis. Sedangkan pada tingkat daerah, pembinaan dan pengawasan dilakukan secara internal oleh pemerintah daerah, institusi internal 
yang menjalankan tugas tersebut adalah Inspektorat (Mawardi, 2020).

Berdasarkan keterangan yang diberikan oleh Inspektur Bener Meriah, Mawardi (2020), tatacara pengawasan yang dilakukan oleh inspektorat hanya dengan melakukan review, hasil review dari pihak inspektorat tersebut akan menjadi syarat pengajuan amprahan untuk pencairan dana kegiatan. Pada tahap penganggaran, pihak inspektorat juga melakukan pengawasan preventif yakni dengan melakukan probity audit. Biasanya probity audit seringkali terkait dengan kegiatan pengadaan barang dan jasa, hal ini dilakukan atas dasar banyak kasus korupsi yang melibatkan aparatur pemerintah berkisar pada kegiatan pengadaan barang dan jasa. Yang dilihat dari audit tersebut adalah proses pengadaan barang dan jasa dilakukan dengan prinsip-prinsip kebenaran, prinsip-prinsip penegakan integritas, dan kejujuran untuk memenuhi ketentuan perundang-undangan yang berlaku, tujuan dilakukannya adalah untuk meningkatkan akuntabilitas penggunaan dana publik.

Selain itu, dijelaskan juga bahwa jika merujuk pada Pasal 116 Peraturan Presiden Nomor 54 Tahun 2010, Lembaga dan Institusi Negara termasuk Pemerintah Provinsi serta Pemerintah Kabupaten/Kota diwajibkan untuk melakukan pengawasan terhadap Pejabat Pembuat Komitmen (PPK), dan Unit Layanan Pengadaan (ULP). Pengawasan yang dimaksud diantaranya mencakup sistem pengawasan internal atas pengadaan barang dan jasa termasuk menugaskan APIP untuk melakukan kerjakerja audit. Ketentuan mengenai APIP ini diatur pada pasal 1 butir 11 Perpres Nomor 54 Tahun 2010, disebutkan bahwa APIP berfungsi sebagai aparat yang melakukan pengawasan melalui audit, review, evaluasi, dan pemantauan dan kegiatan pengawasan lain terhadap penyelenggaraan tugas dan fungsi organisasi.

Berdasarkan keterangan dari Ambal Riyanto, Koordinator Pelaksana Bidang Mitigasi Khusus, yang mengatur hal-hal yang berkaitan dengan korupsi.

Menurut Ambal Riyanto (Koordinator Pelaksana Bidang Mitigasi Khusus terkait Korupsi), pengawasan DOKA secara khusus oleh BPKP tidak ada, namun jika ada surat tugas dari pihak aparat penegak hukum seperti kepolisian, kejaksaan, dan (termasuk) KPK, baru akan dilakukan tindakan pemeriksaan. Tindakan pemeriksaan tersebut akan diperiksa dengan sistem audit mitigasi, biasanya hanya dilakukan pada perkara yang sudah terbukti dan terdapat penyimpangan kegiatan. Disamping itu, BPKP memiliki tugas membantu penyidik untuk melakukan audit investigasi dan audit kerugian negara terkait dengan tindak pidana korupsi. Secara teknis, rincinya pihak BPKP melakukan perhitungan kerugian berdasarkan tugas dari penyidik.

\section{Kendala Pengawasan Dana Otonomi Khusus Aceh}

Terdapat banyak pendapat terkait dengan hambatan dalam pengawasan DOKA. Review dan pengawasan pada instansi pengawasan baik internal (Inspektorat) maupun eksternal (BPK/BPKP) masih bersifat manual dan belum memanfaatkan teknologi secara maksimal, walaupun pada sistem perencanaan ada yang sudah menerapkan E-budgeting (BPKP). Pendapat lain yang juga beberapa kali menjadi penekanan oleh informan adalah aspek personal yang menyatakan persoalan dalam penggunaan anggaran selama ini bukan pada aspek regulasinya tetapi indvidu yang tidak bertindak sesuai dengan regulasi yang sudah cukup lengkap. Meskipun demikian, ada pendapat pula yang mengatakan regulasi yang berubah-ubah juga membuat 
fungsi pengawasan menjadi tidak optimal. Pengelolaan DOKA juga lebih sering dihubungkan dengan pembangunan infrastuktur atau yang berorientasi pada fisik.

Penelitian ini menemukan bahwa ada beberapa kendala utama dalam pengawasan DOKA oleh berbagai lembaga stakeholder yang ada. Pertama, temuan yang paling banyak terdeteksi adalah pemeriksaan yang hanya bersifat formalitas atau hanya bersifat teknis, pemeriksaan semacam ini kerap mengabaikan aspek substansi, padahal pemeriksaan yang fokus pada aspek substansial akan menjadi pengawasan yang bersifat preventif, artinya para pelaksana kegiatan tidak akan berani untuk mengakali pertanggungjawaban hanya pada aspek administrasi saja. Kedua, kolaborasi antar instansi negara tidak berjalan secara signifikan. Dalam hal ini, BPK, BPKP, dan Inspektorat sebagai lembaga pengawas tidak all out dalam melakukan pengawasan DOKA. Ketiga, pengawasan yang dilakukan hanya bersifat monitoring and evaluation dalam rangka memberikan bimbingan dan koordinasi teknis saja. Keempat, kewenangan antar lembaga internal di pemerintahan daerah belum jelas dalam persoalan pengawasan. Kelima, khusus dalam hal ini lembaga inspektorat sebagai lembaga pengawas internal yang bertanggungjawab kepada kepala daerah, memiliki potensi untuk tidak independen dalam tupoksinya sebagai pengawas. Terakhir, kendala lain pada pengawasan DOKA yakni masih lemahnya sistem kelembagaan daerah baik dari sisi Pemerintah Aceh sendiri maupun dari pihak DPR Aceh, kedua lembaga ini masih kurang efektif dalam menjalankan tanggungjawabnya sebagai pelaksana dan pengawas sesuai dengan tupoksi yang ada.

\section{Dampak Pengawasan Dana Otonomi Khusus Aceh terhadap Pemberantasan Korupsi di Aceh}

Dampak dari pengawasan DOKA sangat dikaitkan dengan akuntabilitas dalam perencanaan dan penggunaan anggaran yaitu memastikan wajarnya dan tidaknya sebuah perencanaan apakah sesuai dengan peraturan, tidak adanya penyelewangan dalam eksekusi anggaran dan konsistensi antara perencanaan dan penggunaan anggaran. Akuntabilitas juga berkaitan dengan pentingnya review sebelum keputusan untuk pencairan anggaran, terutama dalam hal ini oleh lembaga inspektorat. Pengawasan DOKA juga dihubungkan peran serta masyarakat melalui NGO yang melakukan pengaduan atau melaporkan penyimpanganpenyimpangan. NGO disebutkan sebagai mata dan telinga dari system penegakkan hukum dalam hal ini terkait penyalahgunaan anggaran (Kejaksaan Tinggi). Dampak pengawasan juga berimplikasi pada kehatian-kehatian dalam penggunaan anggaran yaitu melihat system perencanaan dan pelaksanaan sebagai suatu fungsi yang melekat. Dibawah ini akan diuraikan juga dampak pengawasan DOKA terhadap pencegahan dan penindakan korupsi di Aceh serta langkah pencegahan yang harus dilakukan untuk mencegah korupsi DOKA.

Secara subtantif instrument hukum itu harus detail, artinya ia harus dijabarkan dari yang lebih tinggi (UU) ke hukum yang lebih rendah (Perda/ Qanun dan Peraturan Badan). Selain itu, ianya harus mencakup semua sumber dan segala bentuk pengalokasiannya. Kaiatannya dengan penelitian ini, kiranya akan semakin kokoh pondasi hukum kita seandainya terdapat peraturan yang detail membicarakan bagaimana pengawasan DOKA dilakukan.

Sebab berdasarkan temuan penelitian ini bahwa pengawasan terhadap DOKA itu 
ada, namun DOKA tidak diawasi secara khusus, melainkan diawasi dan dievaluasi secara menyeluruh dalam satu anggaran yang disebut Anggaran Pendapatan dan Belanja Aceh. Ada di sini belum tentu berjalan. Boleh jadi ada secara kelembagaan, namun tidak berjalan di tataran fungsi. Kemudian, pengawasan semacam ini apakah dapat diklaim berdampak positif pada pencegahan dan penindakan korupsi di Aceh menjadi pertanyaan kedua dalam penelitian ini.

Tidak ada data yang dapat dibandingkan atas keberhasilan ini. Sebab, keberhasilan pengawasan itu sejatinya diukur dari seberapa relevan kerja-kerja pengawasan terhadap pencegahan korupsi yang dapat dilihat dari menurunnya angka korupsi pasca atau karena dilakukannya pengawasan terhadap DOKA tersebut. Sebaliknya, jika pengawasan tidak dilakukan maka angka korupsi itupun akan semakin besar. Penelitian ini tidak menemukan adanya data yang dapat menjelaskan hal ini. Data yang berhasil ditemukan dari publikasi yang dilakukan oleh MaTA, terdapat sejumlah kasus (sekitar 22 kasus) yang terindikasi korupsi di Aceh dengan total kerugian negara mencapai 72 Miliar lebih. Dari data tersebut, aktor atau pelaku yang paling dominan dilakukan oleh eksekutif, disusul pihak swasta, perangkat desa, perangkat daerah, dan terakhir oleh legislatif (Mataaceh).

Ada anggapan bahwa pengawasan justru tidak berjalan. Potensi kongkalikong antara Gubernur dan Pemerintah Kabupaten/ Kota malah semakin besar peluangnya. Apa yang terjadi bagi Irwandi dan mantap Bupati Bener Meriah adalah bukti dari sistem pengawasan semacam itu. Mendagri yang mewakili pemerintah pusat sebenarnya memiliki peran, namun hanya berkisar $60 \%$, yaitu terhadap DOKA yang dituangkan dalam program dan kegiatan pemerintah Aceh. Selebihnya, yakni 40\% yang dituangkan dalam APBK diawasi oleh Gubernur.

Model pengawasan semacam inilah yang menurut Raden Sartono (Kasudit Pemerintah Aceh, DIY, dan DKI Jakarta Kemendagari) sebagai salah satu faktor rentannya penyelewengan atau penyimpangan terhadap DOKA. Meski menyebut secara regulasi telah baik, ia menyangsikan proses proposal di level Provinsi. Karenanya, di situlah pengawasan harus benar-benar dikuatkan. Sementara itu, Mochamad Ardian Noervianto (Direktur Fasilitas Dana Perimbangan dan Pinjaman Daerah Kemendagri) turut membenarkan potensi penyelewengan itu. Namun ia menolak jika dikatakan pengawasan tidak berjalan (Republika.Co.Id 2018).

Keterangan Ardian dalam sidang kasus suap Gubernur Aceh sebenarnya malah mengkonfirmasi lemahnya pengawasan yang berdampak pada terjadinya penyimpangan anggaran. Pasalnya, ia menjelaskan bahwa Kemendagri hanya memberi rumusan pertimbangan kepada Kemenkeu untuk kemudian diputuskan oleh Kemenkeu. Setelah dipertimbangkan dan akhirnya DOKA disalurkan, Kemendagri hanya sampai pada memastikan agar pengalokasiannya sesuai dengan UU $11 / 2006$ di mana program perbidangnya bergantung pada justifikasi dari provinsi (Detik.Com 2020).

Dampak negatif dari bentuk pengawasan yang lemah itu juga terlihat dari lempar bola panas antar lembaga negara. Artinya, ketika ada kasus korupsi, semua pihak terkesan tidak bertanggung jawab. Hal ini misalnya telihat dari keterangan Kemenkeu yang menolak pengawasan anggaran ada di mereka. Memang benar bahwa pengawasan itu bukan ranahnya Kemenkeu, namun setidaknya Kemenkeu tidak sekadar 
mengecek secara administrasi capaian serapan anggaran untuk pencairan tahap kedua. Sanksi tegas berupa tidak dicairkannya DOKA pada tahap berikut harus benar-benar menjadi warning ketika rendahnya serapan dan penyelewengan anggaran kerap terjadi (Detik, 2020).

Pernyataan bahwa sistem pengawasan terhadap DOKA itu lemah juga datang dari Syarif Hidayat, Akadmisi FH UII. Menurutnya, selama ini pengawasan DOKA dilakukan oleh DPRA yang dalam praktiknya tentu politis khususnya pada proses penganggaran. Akibatnya, ketika kepentingan DPRA diakomodir oleh eksekutif maka DPRA akan bersikap lunak, bahkan semacam tahu sama tahu (Syarif Hidayat, 2018). Kiranya pengawasan semacam ini pulalah yang menyebabkan penyimpangan DOKA rentan terjadi.

Syahdansyah selaku Jaksa di Kejati Aceh sendiri hanya mengatakan bahwa pengawasan itu tentu berdampak positif, baik yang dilakukan oleh BPKP, Inspektorat, dan lembaga lainnya. Ia melihat bahwa Kementerian Keuangan kiranya juga harus dilibatkan karena mereka yang biasanya menerapkan penalti terhadap serapan anggaran dan ketidaksesuian lainnya. Di sini, selaku jaksa, Syahdansyah mengakui bahwa sebenarnya jaksa tidak bermain di ranah pengawasan. Meski begitu, ada tiga hal yang pernah dilakukan kejaksaan dalam pengawasan APBA-DOKA termasuk di dalamnya, pendampingan dengan memberikan legal opinion sebelum pengerjaan, ada legal asistent untuk melihat kualitas, kuantitas, dan schedule saat proyek berjalan, dan terakhir ada yang namanya legal audit untuk mengevaluasi hasil pekerjaan dari kacamata hukum. Kerja-kerja itu diklaim sangat berdampak positif karena mampu menyelamatkan potensi kerugian negara.
Apa yang dikatakan ini sejalan dengan klaim dari mantan Jaksa Agung RI HM. Prasetyo yang mengatakan bahwa TP4 telah menyelamatan uang negara sebesar 4.000 triliyun rupiah (Tirto.Id, 2020).

Secara umum, klaim tersebut sejatinya telah dibantah dengan buktibukti yang ada. TP4 sendiri telah dibubarkan karena memang dianggap bermasalah. Namun, klaim bahwa pengawasan terhadap DOKA berdampak positif tentu masih mengandung kebenaran. Hanya saja, apakah TP4 benarbenar melakukan tugas-tugas seperti yang dikatakan di atas terhadap DOKA? Alihalih mengklaimnya sebagai prestasi, buktibutki kerja TP4 Aceh dan Kabupaten/ Kota se-Aceh terhadap pengawalan DOKA tidak ditemukan. Pernyataan ini kiranya hanya teoritis semata. Faktanya, jika merujuk ke belakang di mana TP4 itu dibentuk dan bekerja, korupsi DOKA terjadi berulang kali dan masih kuat indikasi penyelewengannya pasca pembubaran lembaga tersebut.

Tingkat partisipasi dalam pengawasan kiranya juga memiliki relevansi yang signifikan terhadap penyimpangan DOKA. Bukan tidak berperan, namun sarana dan prasarana yang mendorong partisipasi itu terbilang minim. Terhadap DOKA, masyarakat nyaris tidak tahu ke mana proses pengalokasian serta sejauh mana informasi serapannya dapat dicari. Aplikasi semacam e-planning dan ebudgeting tidak ada sama sekali terhadap DOKA. Dampaknya, penggunaan anggaran menjadi liar dan tidak terkontrol. Pada level yang lebih luas, dampaknya adalah ancaman terhadap upaya menyejahterakan masyarakat.

Terhadap pengelolaan DOKA ini, LIPI menyebutkan bahwa DOKA tidak diperuntukkan dengan master plan yang jelas. Karenanya kerap terjadi pemborosan anggaran. LIPI kemudian 
menyarankan di bidang pengawasan untuk melakukan penguatan korbinwas oleh legislatif dalam pengawasan DOKA, pembentukan lembaga independent, pembentukan tim khusus oleh pemerintah pusat yang bersifat independent, sinergisitas Badan pengawas dan pemeriksa (BPK, BPKP, dan inspektorat), peningkatan struktur pertanggungjawaban inspektorat provinsi harus ditingkatkan ke level pemerintah pusat, perbaikan dalam tahapan pencairan DOKA, dan pentingnya akses informasi keterbukaan bagi masyarakat terhadap penggunaan dan pengelolaan DOKA.

Sedangkan terhadap penindakan, klaim keberhasilan pengawasan juga tidak memiliki justifikasi yang kuat. Pasalnya, penindakan terhadap penyimpangan DOKA tidak melulu bahkan jarang yang merupakan tindak lanjut dari kerja-kerja pengawasan. Kejaksaan Tinggi Aceh yang diwakili oleh Syahdansyah menguatkan pernyataan ini bahwa Jaksa tidak bergerak di bidang pengawasan. Justru tanpa pengawasan dari pihak lain sekalipun, jika ada penyimpangan yang ditemukan atau dilaporkan tentu akan ditindaklanjuti sesuai hukum.

Penelitian ini pada gilirannya menyimpulkan bahwa DOKA tidak hanya kurangnya pengawasan, pengawasan yang ada tidak berpengaruh apa-apa terhadap penyimpangan atau korupsi DOKA. Sedangkan penindakan yang dilakukan, ianya bukan merupakan hasil dari pengawasan yang dilakukan. BPKP Aceh sedikit berbeda dalam hal ini. Menurutnya, BPKP berperan aktif dalam pengawasan dan setiap ada kasus korupsi pasti akan melibatkan BPKP. Namun, pertanyaannya adalah, apa peran BPKP dalam penindakan yang dilakukan, bukan setelah ada kasus lalu peran itu ditanyakan. Artinya bukan peran mereka di pengadilan atau pada proses penyidikan, tapi sebelum aktifitas penindakan oleh aparat penegak hukum itulah yang hendak dipertanyakan.

BPKP belum mampu menunjukkan data yang menunjukkan korelasi pengawasan dengan pencegahan maupun penindakan terhadap korupsi DOKA. Menurut keterangannya, BPKP memiliki divisi-divisi yang fungsi dan perannya berbeda-beda. Penelitian ini belum mampu mengungkap keterkaitan pengawasan yang dilakukan oleh BPKP terhadap pencegahan dan penindakan korupsi DOKA. Akibat dari lemahnya pengawasan itu, peran penindakan terbilang lebih dominan. Penindakan terhadap korupsi DOKA bahkan terbilang yang paling disorot oleh publik. Meski begitu, bukan berarti aspek penindakan telah sesuai dengan harapan. Problem penindakan merupakan masalah yang perlu diteliti secara tersendiri. Menurut MaTA, kasus-kasus korupsi di Aceh bahkan ada yang mangkrak. Setidaknya ada enam kasus (Mataaceh, 2020). Idealnya, pengawasan yang baik dan dilakukan dengan sungguh-sungguh akan meminimalisir aspek penindakan karena peran pencegahan telah berjalan secara optimal. Kerja pengawasan semacam ini sejatinya harus terintegrasi dan berkorelasi satu sama lainnya.

Buruknya pengawasan dana otonomi khusus Aceh menurut Heru Cahyono diakibatkan gagalnya parlemen di Aceh melakukan fungsi check \& balances. Kondisi itu terjadi seiring munculnya mantan kombatan GAM dalam politik lokal Aceh sebagai kekuatan oligarki baru yang tidak hanya menguasai politik, tetapi juga menguasai jaringan ekonomi Aceh. Mereka yang bertahun-tahun menggalang perang untuk melawan Republik Indonesia, kini mendapat kesempatan untuk menduduki jabatan-jabatan politik penting di pemerintahan. Kendati tanpa didukung oleh pendidikan yang memadai, para mantan anggota GAM mampu 
mendominasi pemerintahan Aceh setelah memenangkan perebutan kekuasaan pada ilkada 2006 dan 2012. Mereka juga menguasai kursi legislatif di tingkat provinsi maupun sejumlah kabupaten/kota di Aceh, khususnya di wilayah-wilayah yang dulu merupakan basis GAM seperti di Aceh Utara, Bireuen, dan Kota Lhokseumawe.

Kuatnya dominasi GAM yang menguasai lembaga legislatif baik di DPRA maupun DPRK menjelaskan mengapa parlemen di Aceh gagal melakukan fungsi check \& balances. Ini tidak mengherankan karena DPRA dikuasai oleh Partai Lokal yang rata-rata anggotanya memiliki pendidikan yang rendah. Akibat kualitas yang rendah, DPRA tidak lagi bicara tentang program pemerintahan, melainkan mereka lebih mengedepankan perjuangan kepentingan. Dengan kondisi demikian, maka tidak mengherankan bila pengucuran dana otonomu khusus Aceh hingga saat ini belum menunjukkan harapan untuk bisa menjadi pengungkit perekenomian Aceh, yang pada akhirnya bisa meningkatkan kesejahteraan masyarakat.

Selain itu, semua sumber mengatakan bahwa DOKA diasumsikan sebagai dana kompensasi dari konflik GAM-RI yang berkepanjangan. Karenanya, para elit yang kebetulan dahulu terlibat dalam konflik merasa berhak atas DOKA. Bahkan tidak jarang sebagain masyarakat juga menganggap korupsi DOKA sebagai "kewajaran" dan sudah seharusnya menjadi hak para mantan kombatan. Sikap-sikap semacam ini terkonfirmasi pula lewat kampanye-kampanye Partai Lokal yang selalu mengaitkan perjuangan mereka dengan apa yang Aceh dapatkan hari ini. Dalam dari itu, mereka mengklaim bahwa apa yang mereka terima belum sepenuhnya direalisasikan oleh Pemerintah Pusat. Sudah sepatutnya apa yang mereka perjuangkan, mereka nikmati pula hasilnya.

Berdasarkan pendapat informan setidaknya disimpulkan terdapat 7 langkah pencegahan korupsi antara lain, faktor integritas personal, penggunaan aplikasi digital dalam setiap tahap pengelolaan anggaran, optimalisasi pelaksanaan Probity Audit yang merupakan hal yang esensial, keterlibatan KPK dan Kementerian Keuangan dalam monitoring dan optimalisasi peran APIP.

Khusus mengenai penggunaan aplikasi digital dalam setiap tahap pengelolaan anggaran, para informan, khususnya yang berasal dari inspektorat mengemukakan bahwa dana alokasi khusus (DAK) sudah menggunakan sistem perbendaharaan online, atau familiar dengan Online Monitoring Sistem Perbendaharaan Anggaran Negara (OMSPAN), sementara dana otonomi khusus belum menggunakan aplikasi tersebut. OM-SPAN merupakan sebuah aplikasi untuk melakukan monitoring transaksi yang dapat diakses melalui jaringan internet, serta menyajikan laporan yang dibutuhkan oleh Direktorat Jenderal Perbendaharaan maupun satuan kerja. Upaya pencegahan terhadap penyelewengan penganggaran DOKA, perlu untuk segera diterapkan sistem perbendaharaan online yang serupa pada penganggaran dan pengelolaan DOKA.

Desentralisasi asimetri yang diberikan kepada daerah sesungguhnya positif. Tetapi, hal tersebut harus dibarengi dengan perbaikan kapasitas kelembagaan birokrasi lokal dan pengawasan yang efektif. Pemerintah pusat perlu memberikan perhatian serius terhadap pembinaan dan peningkatan kapabilitas aparatur sipil negara di daerah. Kondisi ini mengingat birokrasi daerah merupakan mesing penggerak pembangungan yang sangat penting. Dengan meningkatkan kapasitas 
manajemennya, aparatur pemerintah dapat menciptakan insentif guna meningkatkan pelayanan publik.

Selain itu, perlu dibuat pedoman regulasi tentang relasi antara provinsi dan daerah berkenaan dengan DOKA sebagai acuan penting bagi daerah dalam membuat wewenang distribusi dana pengelolaan DOKA dan istimewa. Demikian juga petunjuk teknisnya baru dibuat semudah mungkin. Penggelontoran DOKA seharusnya juga didasarkan pada kesiapan daerah, khususnya kesiapan regulasi, birokrasi, dan aparaturnya. Pemberiannya dilakukan secara bertahap dengan mempertimbangkan hasil evaluasinya. Daerah-daerah yang menunjukkan kemampuan dalam pengelolaan DOKA secara bertahap dapat ditingkatkan besarannya.

\section{Penutup}

Berdasarkan rumusan masalah dalam penelitian ini dapat ditarik dua kesimpulan utama. Pertama, tidak ada sistem pengawasan khusus (juga tidak ada lembaga khusus) yang melakukan pengawasan mulai tahap perencanaan, penganggaran, dan tahap pengimplemantasian DOKA. Pengawasan yang dilakukan selama ini dianggap sama dengan pengawasan terhadap sumber anggaran daerah pada umumnya yang melibatkan berbagai lembaga pengawas baik internal maupun eksternal. Namun peneliti menemukan beberapa perbedaan dalam artian negatif (pengawasan DOKA lebih buruk dari pengawasan sumber anggaran lainnya). Bahkan pengawasan yang dilakukan oleh berbagai pihak tersebut selama ini masih sangat lemah. Kedua, dampak dari sistem pengawasan sebagaimana diterangkan pada poin pertama sama sekali tidak efektif dan dengan sistem yang demikian cenderung membuka peluang terciptanya praktik korupsi sejak awal perencanaan DOKA.

\section{Rekomendasi}

Berdasarkan hasil temuan dalam penelitian ini, terdapat beberapa rekomendasi yang perlu disampaikan kepada beberapa pihak terkait untuk perbaikan proses pengawasan dana otonomi khusus Aceh. Pertama, perlu adanya perubahan mengenai ketentuan pengalokasian DOKA yang berdasarkan serapan, hasil evaluasi, dan kesesuaian peruntukan. Kedua, jika DOKA diperpanjang, maka harus ada jaminan perbaikan sistem, dalam hal ini mesti dirancang sebuah blue print sistem pengawasan DOKA dan penerapan Online Monitoring Sistem Perbendaharaan Anggaran Negara (OM-SPAN) bagi DOKA. Ketiga, selain Lembaga Swadaya Masyarakat (LSM), Perguran Tinggi juga mesti didorong untuk ikut memberi masukan berupa hasil riset yang evaluatif dan konstruktif agar pemanfaatan DOKA tepat sasaran. Dan keempat, perlu penelitian lanjutan misalnya terkait pola pengawasan yang ideal untuk dana otonomi khusus di Aceh, dan di beberapa daerah otonomi khusus lainnya.

\section{Referensi}

Aceh, B. (2019). Profil Kemiskinan dan Ketimpangan Pengeluaran Penduduk Aceh September 2019 (Issue 04).

Anti-Corruption Clearing House. (2017). Abdullah Puteh. https://acch.kpk.go.id/id/jejakkasus/115-abdullah-puteh

Aspinall, E. (2009). Combatants to Contractors: The Political Economy of Peace In Aceh. Indonesia.

Barron Patrick. (n.d.). The Contested Corners of Asia: Subnational Con!ict and International Development Assistance The Case of Aceh, Indonesia. The Asia Fondation, 82.

Cressey, D. R. (1953). Other people's 
Money: A study of the social psychology of embezzlement. Free Press. Glencoe, IL.

Dwi Bowo Rahardjo. (2019). KPK Sebut Enam Provinsi di Indonesia Ini Juara Korupsi. Suarajawatengah.Id. https://jateng.suara.com/read/20 19/04/10/212117/kpk-sebutenam-provinsi-di-indonesia-inijuara-korupsi.

Dwi Hadya Jayani. (2019). Bagaimana Perkembangan Dana Otonomi Khusus untuk Papua dan Aceh? Kata Data. https://databoks.katadata.co.id/da tapublish/2019/08/20/bagaimana -perkembangan-dana-otonomikhusus-untuk-papua-dan-aceh\#.

Haryono Umar. (2012). Pengawasan Untuk Pemberantasan Korupsi. Jurnal Akuntansi \& Auditing 8(2): 110.

Heru Cahyono. (2012). Evaluasi Atas Pelaksanaan Otonomi Khusus Aceh: Gagal Menyejahterakan Rakyat Dan Sarat Konflik Internal. Jurnal Penelitian Politik 9(2): 2. http://ejournal.politik.lipi.go.id/in dex.php/jpp/article/view/227/101

Hidayat, Reja. (2019). Pembubaran TP4 Kejaksaan: Menolak Evaluasi, Menutup Kasus Lama. Tirto.id. https://tirto.id/pembubaran-tp4kejaksaan-menolak-evaluasimenutup-kasus-lama-enzG. September 2020.

Hidayat, Syarief. (2018). Jangan Hanya Andalkan KPK. Universitas Indonesia. https://fh.uii.ac.id/blog/2018/07/ 05/jangan-hanya-andalkan-kpkoleh-syarif-hidayat-s-h-m-hum/. 27 September 2020.

Huberman, M. (1984). Qualitative Data Analysis: A Source Book of New Methods. SAGE Publications.
Kemenkeu. (2020). Kajian Efektivitas Implementasi Dana Otonomi Khusus.

Kementerian Keuangan. (n.d.). Bagaimana Pemanfaatan Dana Otonomi Khusus. Kemenkeu. http://www.djpk.kemenkeu.go.id/? ufaq=bagaimana-pemanfaatandana-otsus.

Masyarakat Transparansi Aceh. (2020). Daftar Kasus Indikasi Korupsi di Aceh. MATA. https://mataaceh.org/daftarkasus-indikasi-korupsi-di-aceh/. 8 Desember 2020.

Kasus Korupsi di Aceh Mangkrak, MaTA Sudah Minta Disupervisi KPK. MATA. https://mataaceh.org/kasuskorupsi-di-aceh-mangkrak/. Desember 2020.

Nashih Nashrullah. (2020). BPS: Aceh Masih Jadi Provinsi Termiskin seSumatra. Republika.Co.Id. https://republika.co.id/berita/q45f pv320/bps-aceh-masih-jadiprovinsi-termiskin-sesumatra.

Pryanka, Adinda. (2018). Pengawasan Lemah Jadi Faktor Pemicu Korupsi Dana Otsus. Republika. https://republika.co.id/berita/nasi onal/hukum/18/07/06/pbg5q443 0-pengawasan-lemah-jadi-faktorpemicu-korupsi-dana-otsus. September 2020.

Rabi'u Abdullahi dan Noorhayati Mansor. (2015). Fraud Triangle Theory and Fraud Diamond Theory. Understanding the Convergent and Divergent for Future Research. International Journal of Academic Research in Accounting, Finance and Management Sciences, Volume 5(4): 39. 
Siregar, S. N. (2012). Pergeserann Masalah Keamanan di Aceh. Jurnal Penelitian Politik 9(2).

Suharyo. (2016). Otonomi Khusus Papua dan Aceh sebagai Perwujudan Implementasi Peranan Hukum dalam Kesejahteraan Masyarakat. Jurnal Rechstvinding (Media Pembinaan Hukum Nasional) 5(3): 323-337.

(2018a). Otonomi Khusus di Aceh dan Papua di Tengah Fenomena Korupsi, Suatu Strategi Penindakan Hukum. Jurnal Penelitian Hukum De Jure 18(3): 306. (2018b). Otonomi Khusus di Aceh dan Papua di Tengah Fenomena Korupsi, Suatu Strategi Penindakan Hukum. Jurnal Penelitian Hukum De Jure 18(3): 305.

https://doi.org/10.30641/dejure. 2018.v18.305-318.

Undang-undang Nomor 11 Tahun 2006 tentang Pemerintahan Aceh.

Wahid, Ahmad Bil. (2019). Dirjen Kemenkeu Jelaskan Pengawasan DOKA di Sidang Staf Irwandi. Detik.com.

https://news.detik.com/berita/d4433766/dirjen-kemenkeujelaskan-pengawasan-doka-disidang-staf-irwandi. 27 September 2020. 
Khairil Akbar, Zahlul Pasha Karim, Nyak Fadlullah, Muhammad Siddiq Armia 